\title{
ON DELAY DIFFERENTIAL EQUATIONS WITH ALMOST PERIODIC BOUNDARY CONDITIONS STARTED FROM DIFFERENT POINTS
}

\author{
TADEUSZ JANKOWSKI
}

Abstract. In this paper, we discuss the problems of existence of extremal solutions of delay differential equations which satisfy almost periodic boundary conditions. Some comparison results are given. Corresponding existence results are also formulated for differential equations having more delayed arguments.

Mathematics subject classification (2000): 34A40, 34A45, 34B10.

Key words and phrases: delay differential inequalities, delay differential equations, monotone iterative technique, extremal solutions.

\section{REFERENCES}

[1] T. JANKowSKI, Differential inequalities with initial time difference, Appl. Anal., 81, (2002), 627-635.

[2] T. JANKOWSKI, Integro-differential inequalities with initial time difference and applications, Acta Math. Hungar., 100, (2003), 329-342.

[3] T. JANKOWSKI, Existence of solutions of boundary value problems for differential equations with delayed arguments, J. Comput. Appl. Math., 156, (2003), 239-252.

[4] T. JANKowsKI, Delay integro-differential inequalities with initial time difference and applications, J. Math. Anal. Appl., 291, (2004), 605-624.

[5] G. S. LadDE, V. LAKShmikANTHAM AND A. S. VATSALA, Monotone iterative techniques for nonlinear differential equations, Pitman, Boston, 1985.

[6] V. Lakshmikantham, A. S. VATSAla, Differential inequalities with initial time difference and applications, J. Inequal. Appl.,3, (1999), 233-244.

[7] V. Lakshmikantham, S. Leela and J. Vasundhara Devi, Another approach to the theory of differential inequalities relative to changes in the initial times, J. Inequal. Appl., 4, (1999), 163-174.

[8] J. J. NIETO, R. RODRÍGUEZ-LóPEZ, Existence and approximation of solutions for nonlinear functional differential equations with periodic boundary value conditions, Computers Math. Appl., 40, (2000), 433-442.

[9] J. J. NieTo, R. RodRíGUEZ-LóPEZ, Remarks on periodic boundary value problems for functional differential equations, J. Comput. Appl. Math., 158, (2003), 339-353. 